\title{
SCIENTIFIC PROCEEDINGS
}

\section{Abstracts of Communications.}

\section{Seventy-third meeting.}

\section{College of the City of New York, February I6, I9I6. \\ President Lusk in the chair.}

$$
49 \text { (III3) }
$$

\section{Concerning the protein content of meat.}

By N. W. JANNeY.

[From the Chemical Laboratory of the Montefiore Home and Hospital for Chronic Invalids, New York.]

The commonly accepted modes of determining the protein content of animal muscle are open to criticism. Thus in such standard works as that of König, ${ }^{1}$ also in Atwater and Bryant's ${ }^{2}$ extensively quoted tables, the protein material has been usually calculated by multiplying the total nitrogen content of the fresh meat in per cent. by the factor 6.25. This, as is known, introduces a considerable source of error, for of the total nitrogen about $\mathbf{I} 3$ per cent. is combined in non-protein substances. Moreover the factor 6.25 is of itself incorrect. It is obtained on the basis of accepting 16 per cent. as the average nitrogen content of meat proteins, whereas it has been recently established in this laboratory that the correct value lies between I6.2 and I6.7 per cent. of the pure muscle proteins of various species.

A second indirect method of calculating the "protein substances" of meat has also been recognized by Atwater and Bryant. According to this procedure the combined weights of the ether

\footnotetext{
${ }^{1}$ König, J., "Chemie der Menschlichen Nahrungs und Genussmittel," Berlin, I903.

${ }^{2}$ Atwater, W. O. and Bryant, A. P., U. S. Dept. of Agriculture, Bull. 28 (rev.), I906.
} 
soluble substances plus the ash is deducted from the total solids of the meat and the result considered as representing protein substance. Likewise this scheme falls short of an accurate determination of the muscle proteins. Indeed even the total nitrogenous substances cannot be thus obtained with precision, for ether removes from meat various bodies containing nitrogen.

The cause of these difficulties and uncertainty has been the lack of an accurate analytical procedure for the direct determination of the proteins in muscle. It was however found practicable to develop such a method, ${ }^{1}$ an improved form of which will appear elsewhere. The principle involved in the modified procedure is coagulation of the muscle in alcohol and the removal of the non-protein material by extraction. When this is carried out with certain precautions it is possible to completely separate the fatty and other non-protein material from the proteins, which can be obtained in a high state of purity.

The results thus arrived at by direct analysis are compared in the following table to those obtained by calculation as above indicated. The computed values exceed that of the protein actually present, by fifteen to twenty per cent. In dietetic and metabolic studies this discrepancy must therefore be considered. A revision of various tables of food analyses in this respect is indicated.

Protein Content of Muscle.

\begin{tabular}{|c|c|c|c|c|}
\hline Species. & $\begin{array}{l}\text { Total Nitrogen } \\
\text { in Muscle. }\end{array}$ & $\begin{array}{l}\text { Protein Calcu- } \\
\text { lated (Total } \\
N \times 6.25)\end{array}$ & $\begin{array}{c}\text { Protein Actually } \\
\text { Present. }\end{array}$ & $\begin{array}{c}\text { Nitrogen }{ }^{2} \text { in } \\
\text { Protein. }\end{array}$ \\
\hline $\begin{array}{l}\text { Dog . . . . . . } \ldots \ldots \ldots \ldots \\
\text { Rabbit. . . . } \ldots \ldots \ldots \ldots \\
\text { Chicken . . } \ldots \ldots \ldots \ldots \ldots \\
\text { Fish (halibut) } \ldots \ldots \ldots \ldots\end{array}$ & $\begin{array}{l}3 \cdot 33 \\
3 \cdot 39 \\
3 \cdot 43 \\
3.10\end{array}$ & $\begin{array}{l}20.8 \\
20.8 \\
21.4 \\
19.4\end{array}$ & $\begin{array}{l}17.9 \\
16.7 \\
17.5 \\
16.7\end{array}$ & $\begin{array}{l}16.3 \\
16.3 \\
16.4 \\
16.4\end{array}$ \\
\hline
\end{tabular}

${ }^{1}$ Janney, N. W., and Csonka, F. A., Jour. Biol. Chem., 1915, XXII, 195.

${ }^{2}$ Not calculated ash free. 